\title{
How to show empathy as a coach: The effects of coaches' imagine- self versus imagine-other empathy on the client's self-change and coaching outcome
}

\author{
Sandra J. Diller ${ }^{1,2}$ (1) $\cdot$ Christina Mühlberger $^{1} \cdot$ Nele Löhlau $^{1} \cdot$ Eva Jonas $^{1}$
}

Accepted: 22 October 2021

(c) The Author(s) 2021, corrected publication 2022

\begin{abstract}
Cognitive empathy, expressed as either imagine-self (imagining oneself in the other's situation) or imagine-other (imagining the other person in his/her situation) empathy, is essential for self-change and satisfaction in coaching. In two studies, we investigated the difference between coaches' imagine-self versus imagine-other empathy. In a survey study $(N 1=242)$, we found that the more important coaches perceived the client's self-change, the more valuable they not only rated empathy in general but also imagine-other (but not imagine-self) empathy in particular. In an experimental study $(N 2=57)$, we manipulated the coaches' imagine-self versus imagine-other empathy and examined the effect on the clients' self-change and coaching satisfaction. The results revealed a positive effect of imagine-other (but not imagine-self) empathy on these coaching outcome factors. Thus, one main practical implication is the relevance of showing imagine-other instead of imagine-self empathy as a coach. However, future research should investigate other personnel development approaches like mentoring or training with regard to imagine-self versus imagine-other empathy.
\end{abstract}

Keywords Coaching $\cdot$ Empathy $\cdot$ Imagine-other $\cdot$ Imagine-self $\cdot$ Self-change $\cdot$ Coaching satisfaction

Within organisations, human resource change approaches like coaching support employees' work performance and develop their future potential as workers in order to increase the competitiveness of the company (Swart et al., 2005). Recent research highlights the success of change approach coaching, which can not only help the client on an individual level but can improve the client's performance as an employee and can contribute to the company's success (Grover \& Furnham, 2016; Jones et al., 2015; Theeboom et al., 2014). Although coaching research faces a few weaknesses, such as studies using mostly coachee self-evaluations or having no randomization nor control group (Blackman et al., 2016), clients seem to be satisfied with coaching, and they also report a change in goal attainment and self-change

Sandra J. Diller

sandra.diller@uni-seeburg.at

1 Department of Psychology, University of Salzburg, Salzburg, Austria

2 Organizational Psychology, Private University Schloss Seeburg, Seeburgstr. 8, 5201 Seekirchen am Wallersee, Austria
(Grover \& Furnham, 2016). The client's change is a central focus of coaching, as the process is meant to promote a progress from a status quo to a target status (Grant, 2012; Greif, 2008). In other words, coaching has "the purpose of achieving some type of change, learning or new level of individual or organizational performance" (p. 15; Boyatzis et al., 2019). While goal attainment indicates a self-change on a broader level (Clutterbuck \& Spence, 2017; Greif, 2017), there are underlying variables that can better explain self-change. In other words, next to reaching his or her goals, a coaching client may go through a process of self-change: from setting a goal that is congruent with oneself until attaining the goal self-determinedly in a way that fits the own will and skill. Thus, knowledge about the self, such as one's own interests, motivation, and values, is necessary to determine one's goals in coaching (Grant, 2014).

To reflect on (self-)concepts, merely paying attention to the self is not enough: Instead, for the purpose of seeing and comparing the actual with the ideal self, people need information on who they are and what they think, want, need, and feel. Therefore, (1) self-access, (2) self-reflection, and (3) self-insight are needed (Grant, 2003, 2014; Greif, 2007, 2008, 2017; Greif \& Berg, 2011; Mäthner et al., 2005; 
Quirin \& Kuhl, 2018; Stein \& Grant, 2014). In other words, it is essential to be able to access, reflect on, and understand oneself. From this process, (4) self-awareness develops, which helps to better set self-valued goals in coaching (Grant, 2003; Greif, 2008; Greif \& Berg, 2011). If goals are self-valued, they are (5) congruent with the own self, which also helps goal attainment (Grant, 2014; Greif, 2008; Klein et al., 2013; Klinger \& Cox, 2004; Quirin \& Kuhl, 2018; Schiemann et al., 2018; Willms, 2004). Furthermore, the more congruent a goal is, the more (6) committed and (7) positively affected a person is towards the respective goal - two factors that are also strongly connected to goal attainment (Eberly et al., 2013; Klein et al., 2013; Latham \& Locke, 1991; Locke \& Latham, 2013; Lyubomirsky et al., 2005; Willms, 2004). For instance, Boyatzis et al. (2013) found that positive affect fostered sustained desired change. In addition, congruency fosters (8) self-regulation, which is also strongly connected to goal attainment (Day \& Unsworth, 2013; Fröhlich \& Kuhl, 2003). In other words, "the process of coaching is essentially about helping individuals regulate" (p. 149; Grant, 2012). This self-regulation needs to be seen compared to self-control: While self-regulation is about acting according to own values to reach something that wants to be reached, self-control is about an effortful striving for something that should be done (Baumann \& Kuhl, 2013) (see also the difference between coaching for compassion versus coaching for compliance; Boaytzis et al., 2012). Coaching is a process in which people do not work on goals that should be attained but work on goals that they really want to attain, i.e., self-congruent goals. In sum, goal attainment needs a certain positivity about the goal, a certain commitment, and a certain awareness of whether this goal fits oneself (Grant, 2014; Klein et al., 2013). The better it fits, the more self-congruency and self-determination is experienced, which helps self-change occur in a congruent way. Thus, coaching is more about fulfilling the need for autonomy, i.e., the need for self-congruency and valuecongruency, than the needs for competence or relatedness (Diller et al., 2020; Schiemann et al., 2018). Consider a coaching client who has been offered a management position and has begun a coaching process to face the new task. The client could be self-aware, for example by reflecting on self-relevant information such as own strengths, weaknesses, and wishes, and by considering their usefulness in the management position (e.g., How can I use my strengths in the new position?). However, the client may only consider information relevant to the company and set their goals according to the expectations of the company (e.g., What do my employees expect from me and how can I address their expectations?). These processes would result in different goals and thus, different processes of self-change. In the first case, the client would develop based on the own self.
In the second case, the client would develop but based on external expectations.

\section{The Power of Empathy for Self-Change}

To foster this self-change, empathy may be an essential factor: Previous research suggests that a coach's empathy is essential for coaching effectiveness (Dagley, 2010; Neukom et al., 2011; Rekalde et al., 2015; Sonesh et al., 2015; Sullivan, 2006). By, for instance, thoroughly listening to the client and expressing understanding, a coach can build a supportive and trustful relationship with the client (Allen, 2016; de Haan et al., 2011; Neukom et al., 2011; Sonesh et al., 2015; Stober, 2006). A trustful relationship is the basis for the client to openly explore and share personal information, emotions, and concerns (Abrams et al., 2003; Mohr \& Spekman, 1994; Van Lange \& Rusbult, 2012; Wasylyshyn, 2019). Thus, empathy not only "promotes a positive working alliance [but also] deconstructs clients' worldviews and assumptions and enhances clients' capacities to regulate their affect" (Watson, 2001; p. 27). In other words, empathy helps the client to more deeply think about own wishes, motivations, and feelings, and also share them with the coach. This means that the coach's empathy not only can benefit the relationship but can also facilitate self-change (Watson et al., 2013). For example, clients who perceive empathic behavior from their coaches, such as when coaches try to understand their clients' points of view, are willing to explore personal topics and share these thoughts with the coach. Thus, experiencing empathetic behavior leads clients to reflect more on their goals and own behavior and more clearly express their feelings (Bachelor, 1988; Behrendt, 2004; Schmidt \& Thamm, 2008). In addition, it has been found that the more important coaches viewed their support of their client's self-congruence, the more empathy they said they showed (Schiemann et al., 2018). In sum, coach's empathy may enable self-change in the client. Yet there are different ways coaches can show empathy, for example, by repeating how the client feels or by sharing their own similar experiences.

\section{Showing Empathy as a Coach}

Empathy can be seen as "multiple distinct but related processes through which people respond to others' emotions" (Zaki, 2017). Even though many definitions exist, recent research agrees on the division of empathy into at least two components: cognitive empathy and emotional empathy (Cuff et al., 2016; Davis, 1983, 2018; Lamm et al., 2007; Wieck et al., 2021; Zaki, 2017). Whereas cognitive empathy comprises operations that help take another person's 
perspective and thus understand the other's emotions, emotional empathy is characterized by feeling and experiencing emotions triggered by perceiving the other person's emotions (Cuff et al., 2016). Similarly, for psychotherapists, empathy is seen as the ability to understand (cognitive) and experience (emotional) the client's feelings without confusing or conflating them with their own feelings and experiences (Atkins, 2013; Staemmler, 2008). Some definitions of empathy even focus on the cognitive aspect, describing empathy as the ability to combine representations and intentions of others with our own opinion about the others' feelings, in order to understand inner processes (Leiberg \& Anders, 2006; Preston \& Hofelich, 2011). This cognitive empathy has often been described as perspective taking (Davis, 1983, 2018; Will et al., 2016); Decety (2005) even called perspective taking "the royal avenue to empathy" (p. 143). When taking the perspective of another person in terms of cognitive empathy, two different ways of doing so can be distinguished.

\section{Imagine-Self Versus Imagine-Other Empathy}

A person can empathize (take another's perspective) by imagining the other (referring to the other person's personality, values, experiences, etc.) in the other's situation (known as the imagine-other $[\mathrm{IO}]$ perspective) or by imagining himor herself (referring to the empathizer's own personality, values, experiences, etc.) in the other's situation (known as the imagine-self [IS] perspective; Batson et al., 1997; Engel, 2015; Stotland, 1969). Most people choose the IS strategy in daily life: In one study (Van Boven et al., 2013), 79\% of participants "explicitly mentioned that they mentally changed places with the [person], imagining how they themselves would react to the [person's] situation" (p. 124). In a second study, again "people were apparently quite willing to identify similar experiences" (p. 126), and this effect increased when there were more similarities between the study participant and the described other person. While IS empathy can be helpful in situations when one has prejudices against another person (Galinsky et al., 2005; Van Boven \& Lowenstein, 2003), it can also lead to personal stress, discomfort, and thinking about oneself instead of the other person (Batson, 2014; Davis et al., 2004; Goldstein et al., 2014; Gouveia et al., 2017; Lawrence et al., 2006; Myers et al., 2014). Thus, IS empathy can lead to more egocentristic views and, therefore, wrong estimations of the target's thoughts and feelings (Van Boven \& Loewenstein, 2005). In contrast, IO empathy leads to empathetic concern, altruistic feelings, and a more detailed exploration of the other person (Batson, 2014; Davis et al., 2004; Goldstein et al., 2014; Gouveia et al., 2017; Lawrence et al., 2006; Myers et al., 2014; Vorauer, 2006).
Thus, it is no wonder that IO empathy seems to be more prevalent in therapy: The therapists' empathy has been described as "decenter[ing] from their own experience and perspectives in order to take on the perspective of the other" (Watson, 2007, p. 67), understanding the client's feelings without confusing it with the own self (Atkins, 2013; Staemmler, 2008), and "entering the private perceptual world of the other" without letting their own referential points distort the perception of the client's world (Rogers, 1975, p. 3). Also, therapy effectiveness measures for empathy, such as the Barrett-Lennard Relationship Inventory (BLRI), define empathy as focusing on the client's point of reference (e.g., "My therapist appreciates exactly how the things I experience feel to me") and not the therapist's own perspectives and attitudes (e.g., "My therapist's own attitudes toward things I do or say prevent him/her from understanding me") (Barrett-Lennard, 2015; Kazdin, 2007; Lambert \& Barley, 2001). Additionally, most therapy clients have described the therapist's empathetic behavior as reformulation, questioning, and interpretation, and they have mentioned nonverbal cues that signal the therapist's understanding (Bachelor, 1988), which is reminiscent of IO behavior. Therefore, IO empathy seems to be the more effective strategy in therapy.

\section{The Present Research: IO or IS Empathy in Coaching?}

Of course, therapy cannot be equated with coaching: Therapy is about healing and stabilizing a person in a clinical setting, while coaching is about empowering a healthy client with a behavioral activation function and goal attainment (Crowe, 2017). And when it comes to empathy, the context is dependent on what kind of empathy is important to show: For instance, helping situations, relationship situations, and negotiation situations need different empathy components (Weisz \& Cikara, 2021). Nevertheless, both therapy and coaching have similar practices and share similarities regarding the client's self-change (Crowe, 2017). As empathy has been highlighted as an essential ingredient in both care professions, as it can help to "feel secure to express their thoughts and problems" (p. 3; Moudatsou et al., 2020), there should be no systematic differences between the two. Thus, IO empathy may also be the preferable strategy for coaching. This assumption on IO empathy can be underlined by recent coaching research on coach behavior: Paraphrasing and verbalizing the client's stated thoughts and feelings have shown to be effective coaching techniques (Magill et al., 2018; Miller \& Rollnick, 2013; Will et al., 2016). To explore the effect of IS and IO empathy on self-change and coaching satisfaction, we conducted two studies on coaches' empathy. In the first study, we asked coaches about their clients' self-change as well as whether they perceived empathy 
in coaching as important, whether they showed empathy, and whether they showed IO and/or IS empathetic behavior. In the second study, we manipulated the coaches' IO and IS perspectives and investigated this manipulation's influence on the clients with regard to the self-change and coaching satisfaction.

\section{Study 1}

In the first study, we asked the coaches about their client's change in self-awareness and goal-related change as well as their empathetic behavior toward their clients. The coach's point of view is needed to better understand the importance of empathy in coaching and whether IO or IS empathy is used more often in regular coaching practice. As empathy can foster self-change, we hypothesized the following for all self-change measures:

H1a: The higher a coach rated the importance of the client's self-change, the more important that coach would think it is to show empathy.

H1b: The higher a coach rated the importance of the client's self-change, the more empathy they would say they show.

As an additional analysis to investigate $\mathrm{H} 1 \mathrm{a}$, we also looked at the qualitative data on why coaches perceive empathy as important. We further proposed that IO but not IS empathy is more linked to self-change and hypothesized the following:

H1c: The higher a coach rated the importance of the client's self-change, the more IO empathy they would show.

As an additional analysis to investigate $\mathrm{H} 1 \mathrm{c}$, we also looked at the qualitative data on how coaches show empathy.

\section{Method}

Participants The study was conducted in cooperation with XING Coaches (https://coaches.xing.com/), an online platform connecting coaches and clients in Germany, Austria, and Switzerland. Participants were 242 coaches (135 female, 107 male) between the ages of 28 and 80 years $(M=52.90$ years, $S D=9.42)$ with coaching experience ranging from 1 to 50 years $(M=13.56$ years, $S D=9.39)$. Most of the coaches $(n=198)$ had completed some form of coach training (see Supplemental Material A). As compensation, the coaches had the opportunity to get the early results via email; for this, they were instructed to send an email to our coaching research email address.
Procedures and Measures The coaches were asked to fill out an online questionnaire hosted on LimeSurvey version 2.67.3, starting with providing informed consent. The aim and duration of the study, data privacy and anonymity, and the possibility to opt out at any time were explained. After the coaches provided their demographic information, including age, gender, coaching experience, and coach training, they were asked about client change factors and, subsequently, their empathy with regard to a typical coaching client. In other words, coaches were asked to fill out what they think clients usually think about self-change in coaching as well as how the coaches usually show empathy. We decided to ask about the usual client, as we were interested in the norm and we were not able to assess whether the last client process was the best example of their usual coaching.

Independent Variable: The Perceived Importance of the client's Self-Change The perceived importance of the client's self-change was measured by one item per change factor (change in self-awareness and goal-related change, including goal attainment as a coaching outcome) that was derived from the definitions mentioned in the Introduction (see Appendix 1 with correlations). All items were assessed on a 10-point Likert scale ranging from 0 (does not apply at all) to 9 (applies very well). To measure the coaches' experience of their clients' need for self-congruence as a self-change mechanism ${ }^{1}$ in more detail, the German translation of the basic psychological need scale (Deci \& Ryan, 2000) was used (two items; $\alpha=.79$ : "My client wants to be him/herself in coaching" and "My client wants to freely express his/her own ideas and opinions in coaching"). The items were rated on a 5-point Likert scale of 1 (does not apply at all) to 5 (applies very well). As expected, coaches rated their client's

\footnotetext{
1 We excluded one item of the autonomy scale because of low reliability ("My client wants to decide for him-/herself how to design the coaching"). Also, competence (three items; $\alpha=.58$ : e.g., "My client wants to feel competent in the coaching") and relatedness (three items; $\alpha=.59$ : e.g., "My client wants to get along well with me as his/her coach") were measured with the same Likert scale. Competence also had a positive effect on the importance of empathy $\left(b=.24, t=3.82, S E=0.11, R^{2}=.06, F(1,240)=14.63\right.$, $p<.001)$, showing empathy $\left(b=.16, t=2.48, S E=0.17, R^{2}=.03\right.$, $F(1,240)=6.15, p=.014)$ and IO empathy $(b=.18, t=2.79$, $\left.S E=0.11, R^{2}=.03, F(1,240)=7.80, p=.006\right)$ but not IS empathy. Relatedness had a positive effect on the importance of empathy $\left(b=.34, t=5.57, S E=0.10, R^{2}=.11, F(1,240)=30.99\right.$, $p<.001)$, showing empathy $\left(b=.15, t=2.33, S E=0.16, R^{2}=.02\right.$, $F(1,240)=5.45, p=.020)$, IO empathy $(b=.18, t=2.78, S E=0.11$, $\left.R^{2}=.03, F(1,240)=7.74, p=.006\right)$, and IS empathy $(b=.17$, $\left.t=2.62, S E=0.17, R^{2}=.03, F(1,240)=6.84, p=.009\right)$. As we concentrated on self-change, we did not include these two need measures. These were just measured to leave the scale as a whole (see also Diller et al., 2020).
} 
Table 1 The influence of the clients' change factors on empathy and IO/IS behavior

\begin{tabular}{|c|c|c|c|c|c|c|c|c|c|c|c|c|}
\hline & \multicolumn{3}{|c|}{$\begin{array}{l}\text { Importance of } \\
\text { empathy }\end{array}$} & \multicolumn{3}{|c|}{$\begin{array}{l}\text { Showing empa- } \\
\text { thy }\end{array}$} & \multicolumn{3}{|c|}{ IO behavior } & \multicolumn{3}{|c|}{ IS behavior } \\
\hline & $\overline{R^{2}}$ & $b$ & SE & $R^{2}$ & $b$ & $\mathrm{SE}$ & $\overline{R^{2}}$ & $b$ & SE & $R^{2}$ & $b$ & SE \\
\hline \multicolumn{13}{|l|}{ Independent variables } \\
\hline Self-access & .10 & $.31 * *$ & .04 & .07 & $.27 * *$ & .06 & .04 & $.21 *$ & .04 & .01 & -.07 & .07 \\
\hline Self-reflection and self-insight & .06 & $.25^{* *}$ & .04 & .04 & $.21^{*}$ & .07 & .14 & $.37 * *$ & .04 & .00 & .06 & .08 \\
\hline Self-congruence (1 item) & .12 & $.35 * *$ & .04 & .06 & $.24 * *$ & .07 & .07 & $.26 * *$ & .05 & .00 & .04 & .08 \\
\hline Self-congruence (Scale) & .12 & $.35^{* *}$ & .10 & .05 & $.21 *$ & .15 & .06 & $.25 * *$ & .10 & .00 & .06 & .17 \\
\hline Goal congruence & .07 & $.27 * *$ & .04 & .05 & $.21 *$ & .06 & .04 & $.20 *$ & .04 & .00 & -.04 & .07 \\
\hline Goal-related positive affect & .19 & $.43 * *$ & .05 & .10 & $.31 * *$ & .08 & .11 & $.33^{* *}$ & .06 & .01 & .10 & .09 \\
\hline Goal commitment & .02 & .15 & .04 & .03 & $.18^{*}$ & .07 & .03 & $.19 *$ & .05 & .00 & -.00 & .07 \\
\hline Self-regulation & .08 & $.28 * *$ & .04 & .04 & $.19^{*}$ & .07 & .05 & $.22 *$ & .05 & .02 & -.13 & .07 \\
\hline Goal attainment & .05 & $.22 *$ & .05 & .03 & $.18^{*}$ & .08 & .08 & $.29 * *$ & .05 & .00 & .03 & .09 \\
\hline
\end{tabular}

$I O$ Imagine-other, $I S$ imagine-self, $b$ standardized coefficient beta, $R^{2} \mathrm{R}$ Square for $b, S E$ standard error for

${ }^{*} p<.006$ (Bonferroni corrected $\mathrm{p}$ value)

$* * p<.001$

self-change high in importance when looking at all means and standard deviations (see Appendix 1).

Dependent Variable: Importance of Empathy The coaches were asked to rate the importance of empathy in coaching on a Likert scale ranging from 0 (not important at all) to 9 (extremely important) $(M=8.27, S D=1.40)$. Furthermore, in an open question afterward, the coaches were asked why they thought empathy was important for coaching ("Why do you think empathy is important for coaching?").

Dependent Variable: Showing Empathy, 10, and IS At first, in an open question, the coaches were asked how they show empathy as a coach ("How do you show empathy as a coach?"). Then, the coach's empathy was quantitively measured by the Barrett-Lennard Relationship Inventory (BarrettLennard, 2015;16 items; $\alpha=.78$; e.g., "It is almost always the case that I know what my client means" [+]; "Sometimes I ignore a few feelings of my clients" [-]) on a 10-point Likert scale ranging from 0 (does not apply at all) to 9 (applies very well $)(M=4.68, S D=2.14)$. IO and IS empathy were measured with Diller et al.'s (2016) ISIO Scale, which is based on the perspective-taking scale of the Interpersonal Reactivity Index (IRI; Davis, 1983). This scale differentiates between IO (three items; $\alpha=.87$; e.g., "I try to imagine how they feel in their place"; $M=8.04, S D=1.47$ ) and IS (three items; $\alpha=.70$; e.g., "I try to imagine how I would feel if I were in their place"; $M=4.63, S D=2.39$ ) perspectives (The original IRI item: "Before criticizing somebody, I try to imagine how I would feel if I were in their place"). All items were rated on a 10-point Likert scale, ranging from 0 (does not apply at all) to 9 (applies very well).
Data Analysis The quantitative data were analyzed via regression analyses with the change factors as predictors and the empathy variables as dependent variables, using the software IBM SPSS Statistic 20. Due to having nine regressions per dependent variable, we used Bonferroni correction, leading to an alpha level of $p_{\text {corrected }}=p / 9=.006$ for statistical significance. The qualitative data were inductively analyzed via qcamap.org by two different raters with backgrounds in psychology; only the ratings that were found by both raters are reported.

\section{Results}

H1a: The relation between the client's change factors and the coach's empathy. As expected, the more important coaches rated their clients' change factors, the more important the coaches rated their own empathy (see Table 1).

H1b: The relation between the client's change factors and the coach showing empathy. The more important the coaches rated their client's change factors, the more empathy the coaches said they showed (see Table 1).

H1c: The relation between the client's change factors and the coach showing IO versus IS empathy. The more important the coaches rated their client's change factors, the more IO empathy the coaches said they showed (see Table 1). Regarding IS empathy, we found no significant effects (see Table 1).

Additional Qualitative Analyses In addition, we qualitatively inductively analyzed the open questions on 1) why 
empathy was rated as important and 2) how the coaches show empathy. Regarding 1) the importance of empathy, the inductive analysis revealed a pattern in which coaches explained (a) in what way empathy serves the coach (e.g., helps the coach understand the client), (b) how this affects the interaction (e.g., leads to a more trustful relationship), and (c) how the client is affected by the improved relationship (e.g., helps the client openly talk about his/her thoughts and feelings). The three most common answers per subgroup (i.e., a through c) were analyzed. Regarding (a), coaches mostly said that empathy helps them understand the client's feelings and motives $(n=78)$ and gives them access to the client $(n=18)$ and the opportunity to be on the same level as the client $(n=12)$. Regarding (b), coaches mostly said that empathy leads to a trusting coaching relationship $(n=81)$, to acceptance $(n=24)$, and to the ability to react to the client adequately $(n=24)$. Finally, regarding (c), empathy can help the client openly talk about his or her thoughts and feelings $(n=23)$, gain self-access and awareness $(n=19)$, and give the client the feeling of being valued with his or her resources $(n=8)$. Regarding 2$)$ the qualitative question on how the coaches show empathy, the coaches mostly listed to show empathy by (actively) listening to the client $(n=93)$, asking questions ( $n=56)$, and showing IO behavior in terms of paraphrasing the client's words or verbalizing the client's feelings $(n=40)$. With regard to IS behavior, it is important to note that 11 coaches said that it is essential to share their own experiences, and 12 coaches stated that it is essential not to show this behavior.

\section{Discussion}

In Study 1, we investigated whether coaches differed in their perception and showing of empathy depending on how important they perceived their client's self-change to be. Taking into account previous coaching and therapy research, we hypothesized that higher ratings of importance of the client change factors would be associated with coaches perceiving empathy as more important, showing more empathy, and showing more IO (but not more IS) empathy. Our quantitative and qualitative results support the hypothesis that in terms of empathy, the IO perspective is more relevant in coaching than the IS perspective. However, this study has some limitations, as only the coach's and not the client's perspective was taken into account. For example, with regard to the coach's empathy, coach and client ratings have been found to differ (Will et al., 2016). Thus, the results may not accurately reflect the client's perception of the coach's empathy and the own change in coaching. Therefore, a second study is needed to investigate the client's perspective. With regard to Blackman et al. (2016), this client perspective should be investigated in a randomized trial, meaning that for our study on empathy, two different empathy conditions are necessary. Thus, we conducted a second study, in which we manipulated coaches' IO and IS behavior to investigate the effect of IO and IS empathy on change factors from the clients' perspective.

\section{Study 2}

To see which empathy strategy might suit the setting of coaching best, in the second study we investigated the role of the coach's IO and IS perspectives. We predicted that clients would be more satisfied with IO than IS empathy because IO is a better match for the coaching setting:

H2a: IO coach behavior should lead to more coaching satisfaction than IS behavior.

We further proposed that IO behavior should have a positive effect on the client's self-change:

H2b: IO coach behavior should lead to more self-change than IS behavior.

\section{Method}

\section{Participants}

Clients "Clients" were recruited from the general student population at [university name blinded for review]. Participation was open to any student older than 18 who spoke fluent German, as long as they were not a psychology student. The last criterion was chosen to avoid coaches and clients having overlapping study goals or study experiences, and to ensure clients had no knowledge of the psychology faculty's research areas. Sixty-two students agreed to participate in the study. Five participants were excluded because they either did not complete the questionnaires (two people) or did not meet the participation criteria (three psychology students), leaving $N=57$ clients. Clients were randomly assigned to a coach (the experimenters made sure that coach and client did not know each other) and to the IO $(n=28)$ or IS $(n=29)$ condition. A quarter of the participants were male (seven in each condition). The participants' age ranged from 18 to 49 years with an average age of about 25 years (IS condition: $M=23.52$ years, $S D=3.70$; IO condition: $M=26.29$ years, $S D=6.75$ ). The two conditions showed similar diversity in the number of semesters completed (IS condition: $M=4.48, S D=2.90$; IO condition: $M=5.00$, $S D=2.77$ ) and fields of study (see Supplemental Material B). In conclusion, the condition samples were comparable in terms of gender, age, study background, and study progress. Study participation was voluntary and the only reward for 
participation was a free 2-h goal-coaching session by a certified coach. The participants were informed that we wanted to investigate the effects of a single coaching session.

Coaches Four coaches were recruited from the alumni list of the coaching program at the university. All had a careercoaching certificate obtained through $220 \mathrm{~h}$ of training, including several workshops, a peer-coaching process, and a supervised client-coaching process. The coaches were aware that they would be participating in a study in which they should coach clients but were unaware of our research questions and blind to our hypotheses.

In preparation for the coaching sessions, the coaches received training in perspective taking. In this 4-h training, the coaches were guided throughout the coaching session and were taught the IS and IO strategies on a behavioral level via exercises and role playing. The coaches did not gain theoretical knowledge about the effects of IS or IO behavior. Although the clients were randomly assigned to the IO or IS condition, coaches necessarily knew which perspective to take. The coaches were briefed not to tell the clients about the two variations and to write down during the coaching session some examples of lines they used to show either IO or IS behavior. Furthermore, their first coaching was taped in order to control for IO IS training success. Time with an external supervisor (without knowledge of our research) was provided to the coaches in case they needed extra help that was not related to the perspective-taking strategy. For their efforts, the coaches received official confirmation of the additional training on perspective taking and credit for their coaching hours.

Procedure The coaching was promoted via the university network as free goal coaching, which supports students in setting and clarifying study- and career-related goals in order to enhance the attainment of these goals. Clients were invited to our coaching room at the university. Preand postcoaching questionnaires, a standardized worksheet, and coaching materials were prepared in the coaching room (all materials were in German). Before the actual coaching started, participants signed the informed consent form and filled out the precoaching questionnaire (about $15 \mathrm{~min}$ ). The coaching sessions (about $90 \mathrm{~min}$ ) were adapted from Braumandl and Dirscherl's (2005) guidelines for a first coaching session. The session started with a short introduction to coaching, while the main part of the coaching focused on concretizing and clarifying the client's goal and defining concrete steps for reaching this goal, as supported by a worksheet. The three most named goals were planning the future career after their studies (53\%), finishing their studies successfully (19\%), and being better at time management and self-management with regard to their studies (16\%; multiple coding possible). In the end, the participants chose a picture that represented their goal. After the coaching, the participants were asked to fill out the postcoaching questionnaire (about $15 \mathrm{~min}$ ).

Measures To investigate the effects of the two perspectivetaking strategies on the coaching process, perspective taking was manipulated (independent variable): The coach showed either IS or IO perspective taking during the whole coaching session. To compare the two groups, the clients received questions on self-change factors with paper-and-pencil preand postcoaching questionnaires. In addition, the postcoaching questionnaire assessed the coach's empathy (directly after the session) as well as the coaching relationship (after the change items but before the coaching outcome measures) and the coaching outcome (at the end).

IO Versus IS Behavior In the IS condition, coaches expressed only IS perspective taking, such as referring to the own perspective or experiences (e.g., "Yes, I know how it feels to have it in the back of your head all the time, but then I always think it would be better if it is done"). In the IO condition, only IO perspective taking was expressed. The coaches referred only to facts they could verbally or nonverbally perceive from the client, through verbal expression (e.g., "So you're saying: On the one hand, you want to make a decision. On the other hand, you do not want to decide because then you need to exclude one of the options. Is that correct?"). Coaches were told to take the client's perspective approximately five to eight times (only in a few cases was it more or less). The number of perspective taking behaviors (either IO or IS behaviors) was counted and noted by the coaches themselves. A t-test for independent samples showed that the number of perspective taking did not differ between the conditions (IO condition: $M=6.18$, $S D=2.02$; IS condition: $M=6.04, S D=2.80$ ), indicating that the number of perspective taking behaviors was similar for both conditions.

Client's Perception of the coach's IO or IS Behavior The client's perception of IO or IS behavior was measured with the ISIO Scale (Diller et al., 2016). Each perspective was measured with three items (IO: $\alpha=.89$; e.g., "The coach tried to imagine how I feel in my situation"; IS: $\alpha=.90$; e.g., "The coach tried to imagine how he/she would feel if he/she were in my place").

Dependent Variables All dependent variables were measured on a 10-point Likert scale ranging from 0 (not at all) to 9 (completely). Dependent variables were the client's perception of the coach's empathy, the client's change factors, and the coaching outcome. A correlation matrix can be found in Appendix 2. The dependent variable means at baseline were comparable in the condition samples. 
Perceived coach's Empathy To measure the coach's empathy as perceived by the client, Barrett-Lennard's Relationship Inventory (Barrett-Lennard, 2015) was adapted to the coaching context (16 items; eight positive and eight negative items that are usually subtracted from each other; positive: $\alpha=.93$, e.g., "My coach understood exactly how the things I experience feel to me" $[+]$; negative: $\alpha=.75$, e.g., "My coach looked at my behavior from his/her own point of view"[-]).

Self-Change Factors To measure situational self-access, we used Quirin and Kuhl's (2018) definition of self-access to create one item (with input from Quirin) that assesses situational self-access: "Right now, I feel like I know precisely who I am, and what I think, want, need, and feel." Furthermore, the clients' degree of self-reflection and selfinsight concerning their goals was measured with the SelfReflection and Insight Scale (Grant et al., 2002), which was adapted in order to have a situational measure (premeasure: "Until now..."; postmeasure: "During the coaching..."). This scale measured self-reflection (six items; $\alpha_{\text {pre }}=.64$; $\alpha_{\text {post }}=.69$; e.g., "...I did not often think about my goal") and self-insight (eight items; $\alpha_{\text {pre }}=.76 ; \alpha_{\text {post }}=.78 ;$ e.g., " ...I was confused about how I really feel about my goal"). Additionally, we created three items to assess self-insight after the coaching ( $\alpha=.81$; e.g., "According to my gut feeling, the thought of my goal feels good after this coaching session") that were derived from the definition of self-insight by Grant $(2003,2014)$. For self-congruence, we measured the subjects' autonomy need fulfillment before and after. As the reliability was very low regarding the basic psychological need questionnaire, we created a scale based on the need definitions provided by Deci and Ryan (2000) and Fiske (2009) (five items; $\alpha_{\text {pre }}=.83 ; \alpha_{\text {post }}=.80$; e.g., "I want to be myself"/"The coaching helped me be myself"). ${ }^{2}$

Goal congruence was measured using the self-concordance scale (Greif, 2008; Sheldon \& Elliot, 1999). Clients rated the reasons for pursuing their goal with four items (intrinsic: I pursue this goal because of the fun and enjoyment that goal would provide me"; identification: "I pursue this goal because I really believe it's an important goal to have"; introjection: "I pursue this goal because I would feel ashamed, guilty, or anxious if I didn't”; external: I pursue this goal because somebody else wants me to or because the

\footnotetext{
2 The fulfillment of the need for competence (five items; $\alpha_{\text {pre }}=.81$; $\alpha_{\text {post }}=.80$; e.g., "I want to show my abilities" / "The coaching helped me show my abilities") and relatedness (five items; $\alpha_{\text {pre }}=.85$; $\alpha_{\text {post }}=.91$; e.g., "I want to get along with others" / "The coaching helped me get along with others") were also measured before and after but are not included in the current analysis based on the relevance of autonomy / sefl-congruency in coaching and the paper's focus on self-change in this regard (see also Diller et al., 2020). The results of these variables can be found in Appendix 3.
}

situation demands it"). The goal congruence score was calculated according to Sheldon and Elliot (1999) by subtracting the introjection and external scores from the sum of the identification and intrinsic scores. To measure goal-related affect, 10 positive adjectives $\left(\alpha_{\text {pre }}=.92 ; \alpha_{\text {post }}=.92\right.$; e.g., "I feel happy about my goal") and 13 negative adjectives $\left(\alpha_{\text {pre }}=.92 ; \alpha_{\text {post }}=.87 ;\right.$ e.g., "I feel unhappy about my goal") were chosen from the Pleasure and Displeasure, Activated Pleasure and Deactivated Displeasure, Pleasant Activation, and Unpleasant Deactivation subscales of the 12-Point Affect Circumplex (12-PAC) Scale (Yik et al., 2011). Clients rated these adjectives on how much they fit their feelings regarding their goals. In a further step, we subtracted the mean score of the negative items from the mean score of the positive items to get a measure of overall goal-related more positive and less negative affect $\left(r_{\text {pre }}=-.48, p_{\text {pre }}<.001\right.$; $\left.r_{\text {post }}=-.45, p_{\text {post }}<.001\right)$. This is essential, as the combination of positive and negative feelings only reveals if there is a more positive affect toward the goal (e.g., you can have a goal you are happy with but also afraid of) (Weber, 2013). To assess goal commitment, five items from the self-report Hollenbeck-Williams-Klein scale were used (Klein et al., $2001 ; \alpha_{\text {pre }}=.61 ; \alpha_{\text {post }}=.71$; e.g., "It is hard for me to take this goal seriously"). Finally, we assessed self-regulation with the Self-Regulation subscale from the short version of the Self-Regulation Inventory (Kuhl \& Fuhrmann, 2004; 12 items; $\alpha_{\text {pre }}=.88 ; \alpha_{\text {post }}=.89$; e.g., "I feel like I pursue this goal voluntarily"). ${ }^{3}$

Coaching Outcome Before and after the coaching session, the goal itself was assessed and goal attainment was measured using three questions formulated on the basis of Greif's (2008) remarks on coaching evaluation. As mentioned before, goal attainment at the end of coaching is a quantitative coaching outcome as coaching goals are set and, therefore, should be achieved during coaching. Clients were asked about the degree of goal attainment ("To what extent have you reached this goal so far?") and their satisfaction with this degree ("How satisfied are you with your current degree of goal attainment?" with the ratings ranging from extremely unsatisfied to extremely satisfied), as well as their confidence in reaching the respective goal ("How confident are you about whether you can reach this goal?" with the

\footnotetext{
3 We also measured self-control, the opposite of self-regulation, with the Self-Regulation Inventory (12 items; $\alpha_{\text {pre }}=.55 ; \alpha_{\text {post }}=.71$; e.g., "Before I start working on my goal, I think about the single steps"/"Now, before I start working on my goal, I think about the single steps") but did not include it in the analysis (see also coaching with compassion versus coaching for compliace (Boyatzis et al., 2013) and self-regulation versus self-control in coaching (Barato \& Rodríguez Moneo, 2021; Baumann \& Kuhl, 2013). The results of these variables can be found in Appendix 3 .
} 
rating ranging from very low to very high). The items were analyzed separately, as they assess quite different aspects of goal attainment. Satisfaction with coaching was measured using eight items adapted from Mäthner et al. (2005; e.g., "I would recommend my coach to others"; "I believe that I will be able to transfer my coaching experiences to everyday life"). In reference to the theory of social exchange (e.g., Rusbult \& Van Lange, 2003), a further item was added to check for the perceived benefit of the coaching: "The coaching session was a mere waste of time." Participants had the chance to further explain these ratings in an open-format area, giving them the opportunity to explain any conspicuously deviant ratings (no disturbing factors were detected). Moreover, items from the Goal-Focused Coaching Skills Questionnaire (Grant \& Cavanagh, 2007) were added and adapted to reflect the client's perspective (instead of the coach's) and to refer to one session instead of a whole coaching process (10 items; e.g., "After this coaching session I have a clear overview of the things that I need to address"); these 10 items correlated highly with the other nine items $(r=.73 ; p<.001)$. Thus, the total coaching satisfaction scale consisted of 19 items $(\alpha=.89)$.

Control Measures for coach's and client's Traits We also measured the client's and coach's personality with the German adaptation of the Ten-Item Personality Inventory (Muck et al., 2007), the client's trait self-access (Self-Access Form; Quirin \& Kuhl, 2018), and the coach's trait empathy (Saarbrückener Persönlichkeitsfragebogen; Paulus, 2009, the German version of the IRI by Davis, 1983; Teachers Report Version of the Relationship Inventory; Barrett-Lennard, 2015). These trait measures did not influence the results and, therefore, are not mentioned in the Results section.

Additional Measure: The Coaching Relationship To measure the client's perception of the coaching relationship, we used the Client Hour Questionnaire (Grawe \& Braun, 1994). Because of low reliability $(\alpha=.36)$, we excluded the reverse-coded item (final: three items; $\alpha=.77$; e.g., "I felt good regarding the relationship with the coach").

Data Analysis Data analyses were done using the software IBM SPSS Statistic 20, with an alpha level of .05 for statistical significance. We ran mediation analyses as not only the coaches' perspective taking strategy but also how clients perceived this perspective taking may influence the outcomes. For these 14 mediation analyses, we used Bonferroni correction, leading to an alpha level of $p_{\text {corrected }}=p / 14=.004$ for statistical significance. We inserted the clients' perceived IO and IS behavior as mediators for the relationship between the coaches' IO vs. IS perspective taking and the dependent variables. This way, we can report both the total effect of the IO and IS manipulation as well as the effect of the perceived IO and IS with consideration of the manipulation as an independent variable. The criteria for the mediation analyses were computed using a $99 \%$ bias-corrected bootstrap confidence interval (99\% BCCI) and 1000 bootstrap samples (Preacher \& Hayes, 2008).

\section{Results}

Perception of the coach's IO or IS Behavior A repeated measures analysis of variance (ANOVA) showed a main effect of the client's perception of the coach's IO or IS behavior, $F(1,55)=43.55, p<.001, \eta_{\mathrm{p}}{ }^{2}=.44$, indicating that overall, clients perceived more IO $(M=7.70, S D=1.38)$ than IS behavior $(M=4.99, S D=2.91)$. There was also a significant interaction between condition and the client's perception of the coach's IO or IS behavior, $F(1,55)=7.89, p=.007$, $\eta_{\mathrm{p}}{ }^{2}=.13$. Pairwise comparisons showed that clients in the IS condition perceived more IS perspective taking $(M=5.82$, $S D=2.63$ ) by their coach than clients in the IO condition $(M=4.14, S D=2.99), p=.029$. Although, the comparison of the clients' perception of IO perspective taking in the IO condition and IS condition did not reach significance, $p=.078$, the means point in the right direction, indicating that clients in the IO condition perceived marginally more IO perspective taking by their coach $(M=8.02, S D=1.02)$ than clients in the IS condition $(M=7.38, S D=1.61)$. Looked at differently, in the IO condition, clients perceived more IO behavior $(M=8.02, S D=1.02)$ than IS behavior $(M=4.14, S D=2.99), p<.001$. However, clients also perceived more IO behavior $((M=7.38, S D=1.61)$ than IS behavior $(M=5.82, S D=2.63), p=.009$ in the IS condition. Summarized, clients perceived more IO than IS behavior by their coach in both conditions.

H2a: The effect of IO and IS empathy on coaching satisfaction. A between-subjects ANOVA showed a significant difference between the IS and IO conditions, $F(1,55)=6.11, p=.017, \eta^{2}=.10$, with the IO clients being more satisfied $(M=7.89, S D=0.70)$ than the IS clients $(M=7.31, S D=1.03)$. A further mediation analysis showed a significant total effect of condition and the mediator, meaning that IO behavior, $p=.017$, and perceived IO, $p=.010$, had a positive influence on coaching satisfaction. Due to Bonferroni correction, however, this result cannot be perceived as significant (see Table 2).

$\mathrm{H} 2 \mathrm{~b}$ : The effect of IO behavior on the client's change factors. As both the coach's actual expressed empathy (actual manipulation) and the client's perception of the coach's empathy (perceived manipulation) were important (Wynn \& Wynn, 2006), we looked at both the coach's actual behavior and the client's perception of the coach's behavior with mediation analyses via Process 2.11 (Hayes, 2013; Model 4). In other words, we computed mediation 


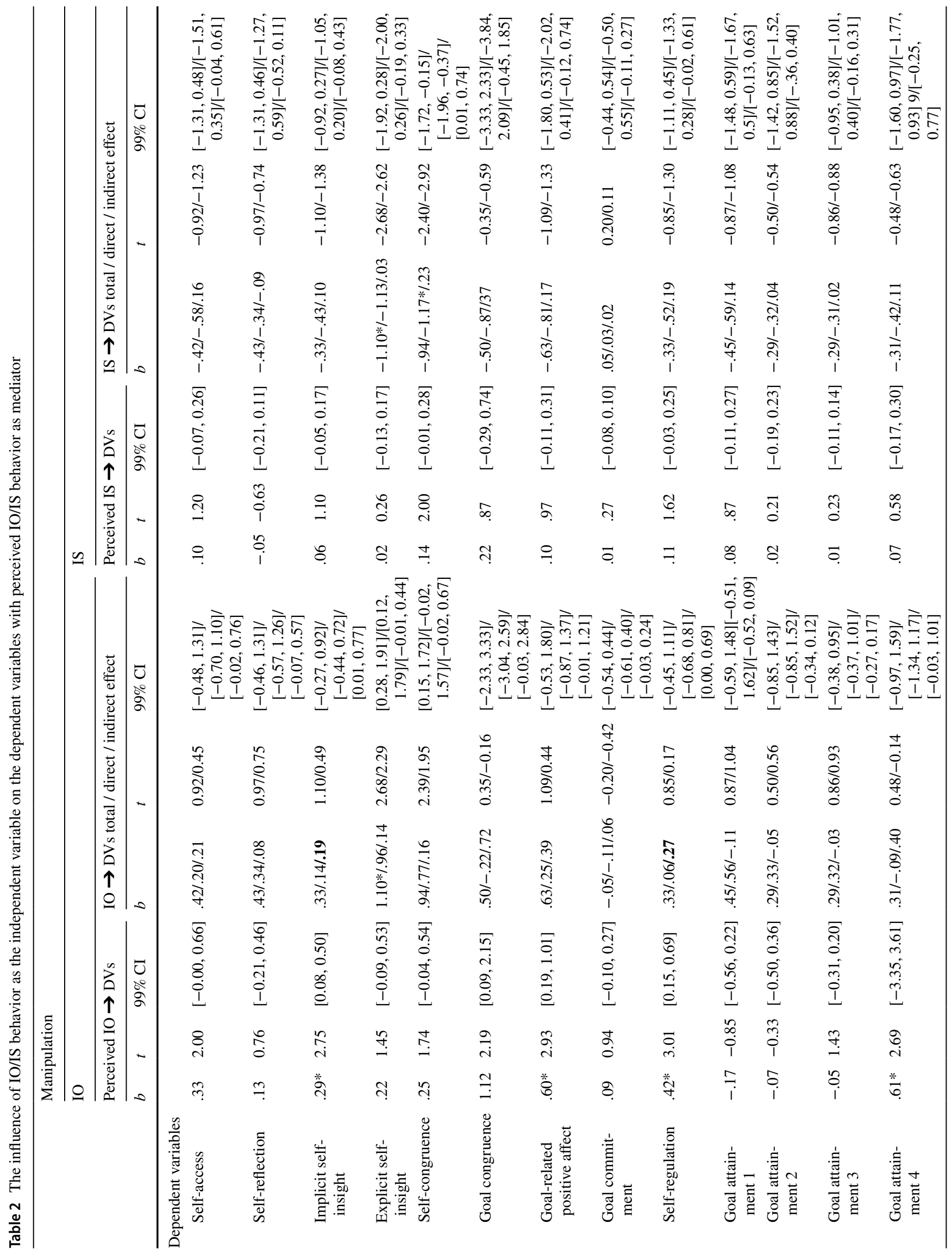




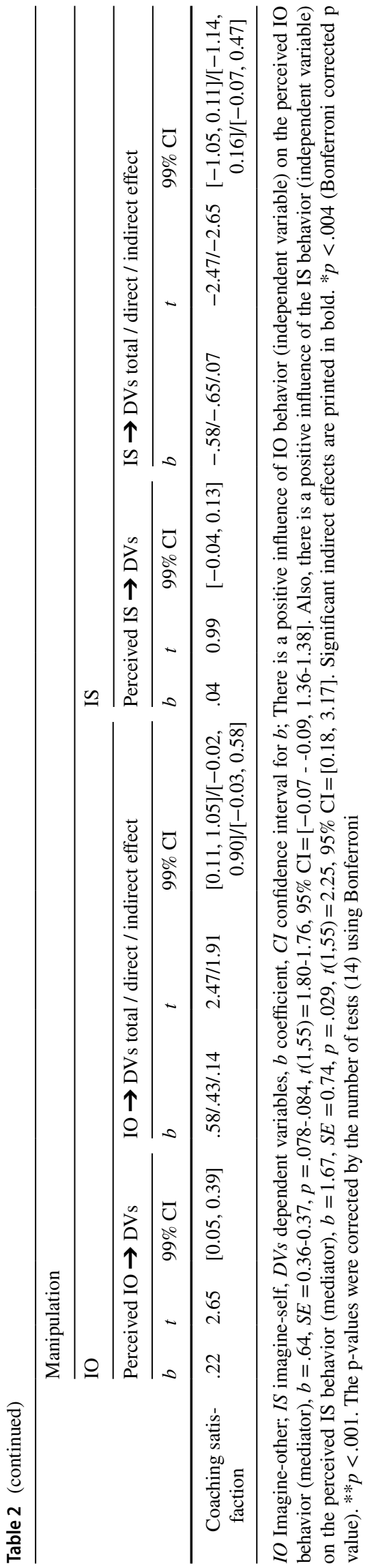

analyses with the coach's actual IO versus IS behavior as the independent variable, the client's perception of the coach's IO or IS behavior as the mediator, and the client's change factors as the dependent variables. Note, most change factors were increased via coaching, regardless of condition (IO or IS). ${ }^{4}$ However, the mediation analyses revealed that even after Bonferroni correction, IO significantly positively influenced the client's implicit self-insight, goal-related positive affect, self-regulation, and goal attainment (see Table 2). Contrarily, IS showed no positive influence and even significantly negatively influenced the client's explicit self-insight and self-congruence (see Table 2).

Additional Finding: The Effect of IO Behavior on Perceived Coach's Empathy The mediation analysis showed that the total effect of IO behavior on perceived empathy was not significant, $b=.68, S E=0.47, p=.151,95 \%$ BCCI $[-0.25$, 1.61]. However, the effect decreased when the potential mediator perceived IO behavior was added, $b=.37$, $S E=0.45, p=.415,[-0.53,1.27]$. IO behavior marginally significantly positively influenced the mediator perceived IO behavior, $b=.64, S E=0.36, p=.078,[-0.07,1.36]$. The mediator had a positive influence on perceived empathy, $b=.48, S E=0.16, p=.005,[0.15,0.81]$. The bootstrapped indirect effect of IO behavior on perceived empathy via perceived IO behavior was significant, $b=.31, S E=0.24,95 \%$ BCCI $[0.02,1.11]$.

\section{Discussion}

In Study 2, we aimed to compare the effect of IO and IS perspective taking on coaching clients. In light of the theoretical and empirical knowledge on empathy as a change factor in psychotherapy, we hypothesized that coaches would be seen as more empathetic and would facilitate the coaching process more effectively when they tried to perceive the client's world through the client's eyes (IO) instead of referring to their own experiences and ideas (IS). To investigate this hypothesis, we asked coaches either to imagine themselves

\footnotetext{
4 A repeated measures ANOVA showed an overall increase in self-access, $F(1,55)=66.39, p<.001, \eta_{\mathrm{p}}^{2}=.55$, self-reflection, $F(1,55)=69.33, p<.001, \eta_{\mathrm{p}}^{2}=.56$, explicit self-insight, $F(1,55)=62.45, p<.001, \eta_{\mathrm{p}}{ }^{2}=.53$ (implicit self-insight was only measured afterward), goal congruence, $F(1,55)=21.18, p<.001$, $\eta_{\mathrm{p}}{ }^{2}=.28$, goal-related affect, $F(1,55)=102.59, p<.001, \eta_{\mathrm{p}}{ }^{2}=.65$, goal commitment, $F(1,55)=7.32, p=.009, \eta_{\mathrm{p}}{ }^{2}=.12$, self-regulation, $F(1,55)=87.41, p<.001, \eta_{\mathrm{p}}{ }^{2}=.61$, and the three goal attainment items, $F_{1}(1,55)=9.02, p=.004, \eta_{\mathrm{p}}{ }^{2}=.14, F_{2}(1,55)=16.13$, $p<.001, \eta_{\mathrm{p}}{ }^{2}=.23, F_{4}(1,55)=44.02, p<.001, \eta_{\mathrm{p}}{ }^{2}=.45$ (the contribution of coaching to goal attainment was only measured afterward).
} 
in the client's position (IS) or to imagine how the clients felt in their specific situation (IO) during a coaching session.

In line with our hypothesis, IO perspective taking by the coach positively affected the client's change in self-awareness, goal-related change, and coaching outcome. These findings indicate that IO does facilitate successful coaching. The results also show that the client-perceived IO behavior was an essential mediator, underlining previous findings where the coach empathy as perceived by the client was highly related to the coaching outcome and coach empathy as perceived by the coach was not (de Haan \& Duckworth, 2012; Gregory \& Levy, 2011; Will et al., 2016). In conclusion, the coach's IO behavior supports the client in the identification of relevant self-aspects. Furthermore, IO behavior led to higher perceived coach's empathy and a better coaching relationship, corresponding to the findings from therapy research.

\section{General Discussion}

The focus of coaching research is on the identification of self-change factors in the coaching process. This identification is crucial, as coaching can only be applied to the right person at the right point in time if one knows under which circumstances coaching is successful (e.g., Grover \& Furnham, 2016). To date, research has suggested that it is not so much specific coach behaviors or techniques that makes coaching effective but common factors such as a good coaching relationship (Behrendt \& Greif, 2018; de Haan et al., 2011). The two studies reported here show that the coach taking an IO perspective is positively related to perceived coach's empathy and supports the client's self-change. More precisely, the coach's IO perspective taking enhances the client's self-awareness, facilitating the exploration of personal wishes and the implementation of resources. As a consequence, the coach's IO perspective taking leads to more goal-related change and a better coaching outcome.

\section{IO Empathy Positively Effecting the Self-Change Process}

As we and others (e.g., de Haan et al., 2012) have noted, empathy can help the coaching relationship. Our results indicate that this positive influence on the coaching relationship is only shown if the coach shows IO empathy. This finding is similar to the results of previous therapy research, in which IO empathy was found to positively influence the therapeutic relationship (Bachelor, 1988; Kazdin, 2007; Lambert \& Barley, 2001). However, empathy may benefit more than just the relationship: Empathy may also facilitate self-insight, self-change, and self-regulation (Watson, 2001; Watson et al., 2013) as it can help the client better reflect on their goals, thoughts, and feelings (Behrendt, 2004; Schiemann et al., 2018; Schmidt \& Thamm, 2008). With regard to our results, as hypothesized, this self-change can be better supported with IO than with IS empathy. In other words, clients are better supported in their self-change when coaches show cognitive empathy by paraphrasing and verbalizing the client's thoughts and feelings instead of by exploring their own thoughts and feelings. Thus, as shown by the results, IO is a favored coaching strategy for supporting the client's self-change (Study 1) and seems to lead to a better coaching outcome (Study 2).

\section{Limitations}

As mentioned in the Discussion of Study 1, there are some limitations when asking coaches about their empathy and the client's self-change. These limitations include self-assessments overall: Both coach (Study 1) and client (Study 2) self-scored their experiences instead of working with videoraters or other more objective measures. In addition, besides the coaches' general coaching training, we have no information about any training in cognitive empathy, their usual coaching topics, or specializations. Furthermore, coaches were asked about a their clients in general rather than a specific client, leaving out questions about their typical client's gender, age, position, or other client information. This is why Study 2 was added to include specific client coachings with equally trained coaches and the client's perspective in a randomized design. Another limitation of Study 1 is that the self-change items are single items that were only derived from the definition of each construct but are not validated scales. This could mean that the construct was measured too simply.

With regard to Study 2, one limitation is that only one coaching session was conducted, whereas change may require more sessions. This limitation may explain the missing findings regarding IO and IS behavior and some change mechanisms, as time is needed for self-access (Quirin \& Kuhl, 2018), self-reflection, and self-regulation (Kuhl \& Fuhrmann, 2004), as well as goal commitment (Klein et al., 2013). Thus, further research should longitudinally examine the whole coaching process. Such a longitudinal perspective can also help to clarify reciprocal interactions between coach and client and the interplay between them (e.g., Li et al., 2014). For instance, a study on empathy in the coaching process shows that the client-perceived coach empathy increased with every coaching session (Diller et al., 2021). In addition, a study on empathy and reciprocity found that both one's own and the other's trait empathy positively influenced cooperative behavior (Bieberstein et al., 2021). A second limitation of Study 2 is the client sample as it consists of students instead of employees. Thus, career goals and age may vary in a working adult sample. Moreover, we 
did not include a real manipulation check for the coaches' perspective taking behaviors. Coaches simply noted their perspective taking behaviors (for the IO condition, for IO behaviors and the IS condition, or only for IS behaviors). A count of how often coaches use both IO and IS behaviors, conducted by a study-unrelated observer via audio-tape / video-tape would serve as a more valid manipulation check. This observer would further be able to give a more processoriented perspective as IO or IS behavior can affect subsequent behavior, possibly leading to different types of conversations. Thus, further research should observe the process in order to help understand the results that were found.

\section{Theoretical Implications}

Based on the limitations of self-assessments, a first theoretical implication regards using not only self-description data but also video data (Will et al., 2016), neuroimaging data (e.g., Lamm et al., 2007), or other more objective measures. Secondly, future investigations should look at whole coaching processes with employed clients instead of students as this may make a difference in terms of goals and goal attainment. Thirdly, coaches of this study not only adopted an IO or IS perspective but were also asked to specifically articulate this perspective. As there may be a difference between thinking in IO or IS terms and articulating IO or IS behavior, further research should examine what happens when, for instance, coaches think about IO but articulate IS empathy, think about IS but articulate IO empathy, or think about IO or IS empathy but do not articulate any perspective taking. A fourth theoretical implication is the inclusion of other experimental groups: In our research, we investigated two different kinds of empathy (two experimental groups) but did not include a condition in which no empathy was shown (control group). This decision was based on our Ethics Committee, as a coaching offer should always include empathy. However, it would be very interesting to take a look at whether no empathy or too much empathy would make a difference in coaching. A fifth theoretical implication comprises the definition of empathy. In our research, we have mainly looked at the situational empathy the coach is motivated to show towards a client based on recent research that empathy should be seen in the situative context (Cameron et al., 2019; Fabi et al., 2019; Zaki, 2017). However, empathy can also be seen as an individual trait or disposition (Aw et al., 2020; Beadle et al., 2012; Davis, 1983, 2018). In addition, we have not yet talked about empathic accuracy as the ability to be accurate in the empathic understanding or on how well this mental simulation in terms of imagining the other's situation works (Packard \& Burnham, 2021). In other words, what happens when emotions do not match or are not mirrored due to, for instance, lack of information or misinformation (Wondra \& Ellsworth, 2015)? Thus, future research should investigate the role of trait empathy and empathic accuracy in coaching.

\section{Practical Implications}

Regarding practical implications, our findings highlight that there is a difference between a coach trying to understand a client by referring to his or her own self (IS) as compared to referring to the client's self (IO). The findings illustrate that referring to the client can enable a much more successful coaching process. Thus, coaches should be aware of this positive effect of the IO perspective on the client's perception of the coach and their relationship, self-change and coaching satisfaction. As people in general are more likely to apply the IS than the IO perspective (Vorauer \& Sasaki, 2014), coaches may face difficulties in applying the IO instead of the IS perspective. As perspective taking is a skill that can be trained (e.g., Atkins, 2013) and was able to be trained in Study 2, an IO perspective training for coaches should be considered. In Study 2, the IO perspective training trained coaches to articulate IO in terms of paraphrasing and verbalizing the client's thoughts and feelings as well as to avoid articulating own opinions and experiences in terms of IS behavior.

\section{Conclusion}

As outlined in the Introduction, practitioners as well as researchers have stressed the importance of empathy in coaching but have not investigated which kind of empathy is preferrable. The present findings yield initial evidence that IO empathy supports the client's self-change and coaching satisfaction. These results should inspire further comparisons of different coaching strategies and their effects on client processes and coaching success. Importantly, the results suggest that coaches should try to imagine the other in terms of recognizing their clients' subjective inner and outer world. 


\section{Appendices}

\section{Appendix 1}

\begin{tabular}{|c|c|c|c|c|c|c|c|c|c|c|c|c|}
\hline Measure & Item(s): "How much do your clients want to... & $M$ & $S D$ & 1 & 2 & 3 & & 4 & 5 & 6 & 7 & 8 \\
\hline $\begin{array}{l}\text { 1. Self- } \\
\text { access }\end{array}$ & $\begin{array}{l}\text {...gain access to themselves and their thoughts } \\
\text { and feelings." }\end{array}$ & 7.32 & 2.13 & - & & & & & & & & \\
\hline $\begin{array}{l}\text { 2. Self- } \\
\text { reflection }\end{array}$ & ...reflect about their goal.“ & 7.39 & 2.03 & $.60 * * *$ & - & & & & & & & \\
\hline \multirow[t]{2}{*}{$\begin{array}{l}\text { 3. Self-con- } \\
\text { gruence }\end{array}$} & $\begin{array}{l}\text {...be more autonomous and feel more in line with } \\
\text { their values and themselves." }\end{array}$ & 7.66 & 2.00 & $.51 * * *$ & $.45 * * *$ & - & & & & & & \\
\hline & + Scale (ranging from 1 to 5 ) & 4.52 & 0.89 & $.31 * * *$ & $.33 * * *$ & $.44 * * *$ & - & & & & & \\
\hline $\begin{array}{l}\text { 4. Goal con- } \\
\text { gruence }\end{array}$ & $\begin{array}{l}\text {... determine their own goal with personal impor- } \\
\text { tance." }\end{array}$ & 7.50 & 2.11 & $.39 * * *$ & $.42 * * *$ & $.35 * * *$ & $25 * * *$ & - & & & & \\
\hline $\begin{array}{l}\text { 5. Goal- } \\
\text { related } \\
\text { positive } \\
\text { affect }\end{array}$ & $\begin{array}{l}\text {...have positive feelings regarding their goal."; } \\
\text {..feel less inhibited, nervous, and anxious." } \\
(-) ; \text {...feel more relaxed, goal oriented, and } \\
\text { energized." }\end{array}$ & 7.60 & 1.64 & $.62 * * *$ & $.56 * * *$ & $.68 * * *$ & $.42 * * *$ & $.43 * * *$ & - & & & \\
\hline $\begin{array}{l}\text { 6. Goal com- } \\
\text { mitment }\end{array}$ & ...develop more commitment to the goal." & 7.01 & 2.08 & $.35 * * *$ & $.44 * * *$ & $.48 * * *$ & $.19 * * *$ & $.37 * * *$ & $.59 * * *$ & - & & \\
\hline $\begin{array}{l}\text { 7. Self-regu- } \\
\text { lation }\end{array}$ & ...find their own way to reach their goal." & 7.32 & 2.08 & $.38 * * *$ & $.38 * * *$ & $.46 * * *$ & $.33 * * *$ & $.36 * * *$ & $.49 * * *$ & $.40 * * *$ & - & \\
\hline $\begin{array}{l}\text { 8. Goal } \\
\text { attainment }\end{array}$ & ...achieve concrete self-chosen goals." & 7.83 & 1.73 & $.36 * * *$ & $.45 * * *$ & $.48 * * *$ & $.35 * * *$ & $.42 * * *$ & $.51 * * *$ & $.40 * * *$ & $.58 * * *$ & - \\
\hline
\end{tabular}

Note. M Mean, SD standard deviation

$* p<.05$

$* * p<.01$

$* * * p<.001$

\section{Appendix 2}

\begin{tabular}{|c|c|c|c|c|c|c|c|c|c|c|c|c|c|c|c|c|c|}
\hline Variable & $M$ & $S D$ & 1 & 2 & 3 & 4 & 5 & 6 & 7 & 8 & 9 & 10 & 11 & 12 & 13 & 14 & 15 \\
\hline 1. Self-access Diff. & 1.82 & 1.69 & - & & & & & & & & & & & & & & \\
\hline $\begin{array}{l}\text { 2. Self-reflection } \\
\text { Diff. }\end{array}$ & 1.83 & 1.66 & .10 & - & & & & & & & & & & & & & \\
\hline $\begin{array}{l}\text { 3. Implicit self- } \\
\text { insight }\end{array}$ & 8.00 & 1.12 & $.33 *$ & .22 & - & & & & & & & & & & & & \\
\hline $\begin{array}{l}\text { 4. Explicit self- } \\
\text { insight Diff. }\end{array}$ & 1.61 & 1.63 & .01 & $.34 * *$ & .13 & - & & & & & & & & & & & \\
\hline $\begin{array}{l}\text { 5. Self-congruence } \\
\text { Diff. }\end{array}$ & -0.30 & 1.54 & $.28 *$ & $.34 * *$ & $.47^{* *}$ & $.30 *$ & - & & & & & & & & & & \\
\hline $\begin{array}{l}\text { 6. Goal congruence } \\
\text { Diff. }\end{array}$ & 3.25 & 5.29 & $.28 *$ & -.10 & .10 & .18 & .21 & - & & & & & & & & & \\
\hline $\begin{array}{l}\text { 7. Goal-related posi- } \\
\text { tive affect Diff. }\end{array}$ & 2.93 & 2.19 & .18 & .25 & .26 & .18 & $.34 * *$ & $.41 * *$ & - & & & & & & & & \\
\hline $\begin{array}{l}\text { 8. Goal commitment } \\
\text { Diff. }\end{array}$ & 0.33 & 0.92 & .17 & .07 & .14 & -.07 & -.05 & .12 & -.03 & - & & & & & & & \\
\hline $\begin{array}{l}\text { 9. Self-regulation } \\
\text { Diff. }\end{array}$ & 1.82 & 1.47 & .22 & $.29 *$ & $.30 *$ & $.27 *$ & $.44 * *$ & $.28^{*}$ & $.53 * *$ & -.11 & - & & & & & & \\
\hline $\begin{array}{l}\text { 10. Goal attain. } 1 \\
\text { Diff. }\end{array}$ & 0.77 & 1.95 & .22 & -.20 & .00 & .07 & -.01 & .19 & -.04 & -.13 & -.10 & - & & & & & \\
\hline $\begin{array}{l}\text { 11. Goal attain. } 2 \\
\text { Diff. }\end{array}$ & 1.14 & 2.13 & .25 & .01 & .03 & -.12 & -.11 & .07 & .02 & -.14 & .12 & $.43^{* *}$ & - & & & & \\
\hline
\end{tabular}




\begin{tabular}{|c|c|c|c|c|c|c|c|c|c|c|c|c|c|c|c|c|c|c|}
\hline Variable & $M$ & $S D$ & 1 & 2 & 3 & 4 & 5 & 6 & 7 & 8 & 9 & 10 & 11 & 12 & 13 & 14 & 15 & 16 \\
\hline $\begin{array}{l}\text { 12. Goal attain. } 3 \\
\text { Diff. }\end{array}$ & 1.11 & 1.25 & -.04 & .08 & .19 & .06 & .01 & -.06 & .15 & .12 & .05 & -.17 & $-.39 * *$ & - & & & & \\
\hline $\begin{array}{l}\text { 13. Goal attain- } \\
\text { ment } 4\end{array}$ & 4.81 & 2.40 & $.34 * *$ & .06 & .23 & -.04 & -.06 & -.02 & .22 & .19 & .23 & -.04 & .19 & .07 & - & & & \\
\hline $\begin{array}{l}\text { 14. Coaching satis- } \\
\text { faction }\end{array}$ & 7.60 & 0.92 & $.39 * *$ & $.32 *$ & $.60 * *$ & .21 & $.49 * *$ & .01 & $.36^{* *}$ & -.18 & $.32 *$ & -.03 & -.02 & .15 & $.35 * *$ & - & & \\
\hline 15. Perceived IO & 7.70 & 1.38 & $.28^{*}$ & .13 & $.37 *$ & .26 & $.29 *$ & $.29 *$ & $.39 * *$ & .12 & $.42 * *$ & -.08 & -.03 & -.03 & $.35^{* *}$ & $.39 * *$ & - & \\
\hline 16. Perceived IS & 4.99 & 2.91 & .12 & -.12 & .10 & -.07 & .15 & .10 & .08 & .04 & .17 & .08 & .01 & .00 & .06 & .03 & -.06 & - \\
\hline
\end{tabular}

Diff. = Difference score (after manipulation - before manipulation); $M=$ Mean; $S D=$ standard deviation; IO=Imagine-other; IS = imagine-self; attain. = attainment ${ }^{*} p<.05 . * * p<.01 . * * *<<.001$. Goal attainment 1 : "To what extent have you reached this goal so far?", Goal attainment 2: "How satisfied are you with your current degree of goal attainment?", Goal attainment 3: "How confident are you about whether you can reach this goal?", Goal attainment 4: "What is the impact of coaching on your goal attainment?"

\section{Appendix 3}

\begin{tabular}{|c|c|c|c|c|c|c|c|c|c|c|c|c|}
\hline & \multicolumn{12}{|c|}{ Manipulation } \\
\hline & \multicolumn{6}{|l|}{$\mathrm{IO}$} & \multicolumn{6}{|l|}{ IS } \\
\hline & \multicolumn{3}{|c|}{ Perceived IO $\rightarrow$ DVs } & \multicolumn{3}{|c|}{ IO $\rightarrow$ DVs total / direct / indirect effect } & \multicolumn{3}{|c|}{ Perceived IS $\rightarrow$ DVs } & \multicolumn{3}{|c|}{ IS $\rightarrow$ DVs total / direct / indirect effect } \\
\hline & $b$ & $t$ & $99 \%$ CI & $b$ & $t$ & $99 \%$ CI & $b$ & $t$ & $99 \%$ CI & $b$ & $t$ & $99 \% \mathrm{CI}$ \\
\hline $\begin{array}{l}\text { Compe- } \\
\text { tence } \\
\text { need }\end{array}$ & .16 & 1.10 & $\begin{array}{c}{[-0.23} \\
0.55]\end{array}$ & $.53 / 43 / .10$ & $1.37 / 1.08$ & $\begin{array}{c}{[-0.50} \\
1.56] / \\
{[-0.63} \\
1.49] / \\
{[-0.12} \\
0.57]\end{array}$ & -.08 & -1.10 & $\begin{array}{c}{[-0.26} \\
0.11]\end{array}$ & $-.53 /-.66 / .13$ & $-1.37 /-1.63$ & $\begin{array}{c}{[-1.56,} \\
0.50] / \\
{[-1.74,} \\
0.42] / \\
{[-0.28,} \\
0.54]\end{array}$ \\
\hline $\begin{array}{l}\text { Related- } \\
\text { ness } \\
\text { need }\end{array}$ & -.04 & -0.20 & $\begin{array}{c}{[-0.52} \\
0.44]\end{array}$ & $-.17 /-.15 /-.02$ & $-0.36 /-0.30$ & $\begin{array}{c}{[-1.45,} \\
1.10] / \\
{[-1.47} \\
1.18] / \\
{[-0.33} \\
0.40]\end{array}$ & -.14 & -1.65 & $\begin{array}{c}{[-0.37} \\
0.09]\end{array}$ & $.17 /-.07 / .24$ & $0.36 /-0.13$ & $\begin{array}{c}{[-1.10,} \\
1.45] / \\
{[-1.38,} \\
1.25] / \\
{[-0.09} \\
0.71]\end{array}$ \\
\hline $\begin{array}{l}\text { Self con- } \\
\text { trol }\end{array}$ & .16 & 1.08 & $\begin{array}{c}{[-0.24} \\
0.56]\end{array}$ & $.26 / .15 / .10$ & $0.65 / 0.38$ & $\begin{array}{c}{[-0.80,} \\
1.32] / \\
{[-0.94,} \\
1.24] / \\
{[-0.14,} \\
0.68]\end{array}$ & -.09 & -1.29 & $\begin{array}{c}{[-0.28} \\
0.10]\end{array}$ & $-.26 /-.41 / .15$ & $-0.65 /-1.00$ & $\begin{array}{c}{[-1.32,} \\
0.80] / \\
{[-1.52,} \\
0.69] / \\
{[-0.12} \\
0.57]\end{array}$ \\
\hline
\end{tabular}

$\mathrm{IO}=$ Imagine-other; IS = imagine-self; DVs = dependent variables; $b=$ coefficient; $\mathrm{CI}=$ confidence interval for $b$; There is a positive influence of IO behavior (independent variable) on the perceived IO behavior (mediator), $b=.64, S E=0.36, p=.078, t(1,55)=1.80,99 \% \mathrm{CI}=[-0.31$, 1.60]. Also, there is a positive influence of the IS behavior (independent variable) on the perceived IS behavior (mediator), $b=1.67, S E=0.74$, $p=.029, t(1,55)=2.25,99 \% \mathrm{CI}=[0.31,3.66]$. There were no significant effects 
Supplementary Information The online version contains supplementary material available at https://doi.org/10.1007/s12144-021-02430-y.

Data Availability Statement The quantitative data that supports the findings of these studies are available to the reviewers upon request in Open Science Framework with a CC-By Attribution 4.0 International License (DOI: https://doi.org/10.17605/OSF.IO/M2B8K). The qualitative raw data that supports the findings of these studies are available upon reasonable request, as this data includes personal information and needs to be securely exchanged due to data-handling restrictions.

Funding Open access funding provided by Paris Lodron University of Salzburg.

\section{Declarations}

This work has not been published elsewhere nor is it currently under consideration for publication elsewhere. The studies were approved by the Ethics Committee and there is an informed consent from all participants from both studies (this can be provided in German if needed).

Conflict of Interest We confirm that we have no conflicts of interest to disclose.

Open Access This article is licensed under a Creative Commons Attribution 4.0 International License, which permits use, sharing, adaptation, distribution and reproduction in any medium or format, as long as you give appropriate credit to the original author(s) and the source, provide a link to the Creative Commons licence, and indicate if changes were made. The images or other third party material in this article are included in the article's Creative Commons licence, unless indicated otherwise in a credit line to the material. If material is not included in the article's Creative Commons licence and your intended use is not permitted by statutory regulation or exceeds the permitted use, you will need to obtain permission directly from the copyright holder. To view a copy of this licence, visit http://creativecommons.org/licenses/by/4.0/.

\section{References}

Allen, K. (2016). Theory, research, and practical guidelines for family life coaching. Springer International. https://doi.org/10.1007/ 978-3-319-29331-8

Atkins, P. W. (2013). Empathy, self-other differentiation and mindfulness. In P. W. Atkins, K. Pavlovich, \& K. Krahnke (Eds.), Organizing through empathy (pp. 49-70). Routledge.

Aw, S. S. Y., Ilies, R., \& De Pater, I. E. (2020). Dispositional empathy, emotional display authenticity, and employee outcomes. Journal of Applied Psychology, 105(9), 1036-1046. https://doi.org/10. 1037/apl0000471

Bachelor, A. (1988). How clients perceive therapist empathy: A content analysis of "received" empathy. Psychotherapy, 25(2), 227-240. https://doi.org/10.1037/h0085337

Barato, J. B., \& Rodríguez Moneo, M. (2021). Can coaching contribute to the development of self-regulation? Similarities and differences between these two processes. Coaching: An International Journal of Theory, Research and Practice, 1-14. https://doi.org/ 10.1080/17521882.2021.1929362

Barrett-Lennard, G. T. (2015). The relationship inventory: A complete resource and guide. Wiley Blackwell.

Batson, C. (2014). Empathy-induced altruism and morality: No necessary connection. In H. Maibom (Ed.), Empathy and morality. Oxford University Press. https://doi.org/10.1093/acprof:oso/ 9780199969470.003 .0002
Batson, C. D., Early, S., \& Salvarani, G. (1997). Perspective taking: Imaging how another feels versus imaging how you would feel. Personality and Social Psychology Bulletin, 23(7), 751-758. https://doi.org/10.1177/0146167297237008

Baumann, N., \& Kuhl, J. (2013). Selbstregulation und Selbstkontrolle [self-regulation and self-control]. In W. Sarges (Ed.), Management-Diagnostik (pp. 263-271). Hogrefe.

Beadle, J. N., Keady, B., Brown, V., Tranel, D., \& Paradiso, S. (2012). Trait empathy as a predictor of individual differences in perceived loneliness. Psychological Reports, 110(1), 3-15. https:// doi.org/10.2466/07.09.20.pr0.110.1.3-15

Behrendt, P. (2004). Wirkfaktoren im Psychodrama und Transfercoaching [Success factors in psycho dra, a and transfer coaching]. Albert Ludwig University of Freiburg. Unpublished manuscript.

Behrendt, P., \& Greif, S. (2018). Erfolgsfaktoren im Coachingprozess [success factors in the coaching process]. In S. Greif, H. Möller, \& W. Scholl (Eds.), Handbuch Schlüsselkonzepte im Coaching (pp. 163-172). Springer. https://doi.org/10.1007/978-3-66249483-7_81

Bieberstein, F., Essl, A., \& Friedrich, K. (2021). Empathy: A clue for prosocialty and driver of indirect reciprocity. PLoS One, 16(8), e0255071. https://doi.org/10.1371/journal.pone.0255071

Blackman, A., Moscardo, G., \& Gray, D. E. (2016). Challenges for the theory and practice of business coaching: A systematic review of empirical evidence. Human Resource Change Review, 15(4), 459-486. https://doi.org/10.1177/1534484316673177

Boyatzis, R. E., Smith, M. L., \& Beveridge, A. J. (2013). Coaching with compassion: Inspiring health, well-being, and change in organizations. The Journal of Applied Behavioral Science, 49, 153-178. https://doi.org/10.1177/0021886312462236

Boyatzis, R. E., Smith, M. L., \& Van Oosten, E. (2019). Helping people change: Coaching with compassion for lifelong learning and growth. Harvard Business Review Press.

Braumandl, I., \& Dirscherl, B. (2005). Career coaching. Cobece training institute, Germany. Unpublished coach training concept.

Cameron, C. D., Hutcherson, C. A., Ferguson, A. M., Scheffer, J. A., Hadjiandreou, E., \& Inzlicht, M. (2019). Empathy is hard work: People choose to avoid empathy because of its cognitive costs. Journal of Experimental Psychology: General, 148(6), 962-976. https://doi.org/10.1037/xge0000595

Clutterbuck, D. A., \& Spence, G. (2017). Working with goals in coaching. In T. Bachkirova, G. Spence, \& D. Drake (Eds.), The sage handbook of coaching (pp. 218-237). Sage.

Crowe, T. (2017). Coaching and psychotherapy. In T. Bachkirova, G. Spence, \& D. Drake (Eds.), The sage handbook of coaching (pp. 85-101). Sage.

Cuff, B. M., Brown, S. J., Taylor, L., \& Howat, D. J. (2016). Empathy: A review of the concept. Emotion Review, 8(2), 144-153. https:// doi.org/10.1177/1754073914558466

Dagley, G. R. (2010). Exceptional executive coaches: Practices and attributes. International Coaching Psychology Review, 5(1), $63-80$.

Davis, M. H. (1983). Measuring individual differences in empathy: Evidence for a multidimensional approach. Journal of Personality and Social Psychology, 44(1), 113-126. https://doi.org/10. 1037/0022-3514.44.1.113

Davis, M. H. (Ed.). (2018). Empathy: A social psychological approach. Routledge.

Davis, M. H., Soderlund, T., Cole, J., Gadol, E., Kute, M., Myers, M., \& Weihing, J. (2004). Cognitions associated with attempts to empathize: How do we imagine the perspective of another? Personality and Social Psychology Bulletin, 30(12), 1625-1635. https://doi.org/10.1177/0146167204271183

Day, D. V., \& Unsworth, K. L. (2013). Goals and self-regulation: Emerging perspectives across levels and time. In E. A. Locke 
\& G. P. Latham (Eds.), New changes in goal setting and task performance (pp. 158-176). Routledge/Taylor \& Francis.

De Haan, E., \& Duckworth, A. (2012). The coaching relationship and other 'common factors' in executive coaching outcome. In E. de Haan \& C. Sills (Eds.), Coaching relationships: Relational coaching field book (pp. 185-196). Libri.

De Haan, E., Culpin, V., \& Curd, J. (2011). Executive coaching in practice: What determines helpfulness for clients of coaching? Personnel Review, 40(1), 24-44. https://doi.org/10.1108/00483 481111095500

De Haan, E., Duckworth, A., Birch, D., \& Jones, C. (2012). Executive coaching outcome research: The contribution of common factors such as relationship, personality match, and self-efficacy. Consulting Psychology Journal, 65(1), 40-57.

Decety, J. (2005). Perspective taking as the royal avenue to empathy. In B. F. Malle \& S. D. Hodges (Eds.), Other minds: How humans bridge the divide between self and other (pp. 135-149). Guilford Publications.

Diller, S. J., Mühlberger, C., \& Jonas, E. (2016). ISIO Scale. University of Salzburg. Unpublished scale.

Diller, S. J., Muehlberger, C., Braumandl, I., \& Jonas, E. (2020). Supporting students with coaching or training depending on their basic psychological needs. International Journal of Mentoring and Coaching in Education, 10(1), 84-100. https://doi.org/10. 1108/ijmce-08-2020-0050

Diller, S. J., Mühlberger, C., \& Jonas, E. (2021). The empathy factor: Empathy as a success factor in each career coaching session. Manuscript under review.

Eberly, M. B., Liu, D., \& Terence, R. M. (2013). Attributions and emotions as mediators and/or moderators in the goal-striving process. In E. A. Locke \& G. P. Latham (Eds.), New changes in goal setting and task performance (pp. 59-74). Routledge.

Engel, V. (2015). Imagine-self vs. imagine-other: Further evidence for the distinction between two types of perspective taking with different emotional consequences. University text.

Fabi, S., Weber, L. A., \& Leuthold, H. (2019). Empathic concern and personal distress depend on situational but not dispositional factors. PLoS One, 14, article e0225102. https://doi.org/10.1371/ journal.pone. 0225102

Fiske, S. T. (2009). Social beings: Core motives in social psychology. Wiley.

Fröhlich, S. M., \& Kuhl, J. (2003). Das Selbststeuerungsinventar [the self-regulation inventory]. In J. Stiensmeier-Pelster \& F. Rheinberg (Eds.), Diagnostik von Motivation und Selbstkonzept (pp. 221-257). Hogrefe.

Galinsky, A. D., Ku, G., \& Wang, C. S. (2005). Perspective-taking and self-other overlap: Fostering social bonds and facilitating social coordination. Group Processes \& Intergroup Relations, 8(2), 109-124. https://doi.org/10.1177/1368430205051060

Gessnitzer, S., \& Kauffeld, S. (2015). The working alliance in coaching: Why behaviour is the key to success. The Journal of Applied Behavioral Science, 51(2), 177-197. https://doi.org/10.1177/ 0021886315576407

Goldstein, N. J., Vezich, I. S., \& Shapiro, J. R. (2014). Perceived perspective taking: When others walk in our shoes. Journal of Personality and Social Psychology, 106(6), 941-960. https://doi. org/10.1037/a0036395

Gouveia, L., Janvier, A., Dupuis, F., Duval, M., \& Sultan, S. (2017). Comparing two types of perspective taking as strategies for detecting distress amongst parents of children with cancer: A randomised trial. PLoS One, 12(4). https://doi.org/10.1371/journ al.pone. 0175342

Grant, A. M. (2003). The impact of life coaching on goal attainment, metacognition and mental health. Social Behavior and Personality, 31(3), 253-263. https://doi.org/10.2224/sbp.2003.31.3.253
Grant, A. M. (2012). An integrated model of goal-focused coaching: An evidence-based framework for teaching and practice. International Coaching Psychology Review, 7(2), 146-165.

Grant, A. M. (2014). Autonomy support, relationship satisfaction and goal focus in the coach-coachee relationship: Which best predicts coaching success? Coaching, 7(1), 18-38. https://doi.org/ $10.1080 / 17521882.2013 .850106$

Grant, A. M., \& Cavanagh, M. (2007). The goal-focused coaching skills questionnaire: Preliminary findings. Social Behavior and Personality: An International Journal, 35(6), 751-760. https:// doi.org/10.2224/sbp.2007.35.6.751

Grant, A. M., Franklin, J., \& Langford, P. (2002). The self-reflection and insight scale: A new measure of private self-consciousness. Social Behavior and Personality, 30(8), 821-836. https://doi.org/ 10.2224/sbp.2002.30.8.821

Grawe, K., \& Braun, U. (1994). Qualitätskontrolle in der Psychotherapiepraxis [quality control in psychotherapy]. Zeitschrift für Klinische Psychologie, 23, 242-267.

Gregory, J. B., \& Levy, P. E. (2011). It's not me, it's you: A multilevel examination of variables that impact employee coaching relationships. Consulting Psychology Journal, 63(2), 67-88. https://doi. org/10.1037/a0024152

Greif, S. (2007). Advances in research on coaching outcomes. International Coaching Psychology Review, 23, 220-247.

Greif, S. (2008). Coaching und ergebnisorientierte Selbstreflexion. Hogrefe.

Greif, S. (2017). Researching outcomes of coaching. In T. Bachkirova, G. Spence, \& D. Drake (Eds.), The sage handbook of coaching (pp. 596-588). Sage.

Greif, S., \& Berg, C. (2011). Result-oriented self-reflection-Report on the construct validation of theory-based scales. University of Osnabrück. Retrieved from http://www.home.uni-osnabrueck.de/ sgreif/english/downloads.html

Grover, S., \& Furnham, A. (2016). Coaching as a changeal intervention in organizations: A systematic review of its effectiveness and the mechanisms underlying it. PLoS One, 11(7). https://doi.org/10. 1371/journal.pone.0159137

Hayes, A. F. (2013). Introduction to mediation, moderation, and conditional process analysis: A regression-based approach. Guilford Press. https://doi.org/10.1111/jedm.12050

Kazdin, A. E. (2007). Mediators and mechanisms of change in psychotherapy research. Annual Review of Clinical Psychology, 3(1), 1-27. https://doi.org/10.1146/annurev.clinpsy.3.022806.091432

Klein, H. J., Wesson, M. J., Hollenbeck, J. R., Wright, P. M., \& DeShon, R. P. (2001). The assessment of goal commitment: A measurement model meta-analysis. Organizational Behavior and Human Decision Processes, 85(1), 32-55. https://doi.org/ 10.1006/obhd.2000.2931

Klein, H. J., Molloy, J. C., \& Brinsfield, C. T. (2012). Reconceptualizing workplace commitment to redress a stretched construct: Revisiting assumptions and removing confounds. Academy of Management Review, 37(1), 130-151.

Klein, H. J., Cooper, J. T., \& Monahan, C. A. (2013). Goal commitment. In E. A. Locke \& G. P. Latham (Eds.), New changes in goal setting and task performance (pp. 65-89). Routledge/Taylor \& Francis.

Klinger, E., \& Cox, W. M. (2004). Motivation and the theory of current concerns. In W. M. Cox \& E. Klinger (Eds.), Handbook of motivational counseling (pp. 3-27). Wiley.

Kuhl, J. (2002). A functional-design approach to motivation and selfregulation: The dynamics of personality systems and interactions. In M. Boekaerts, P. R. Pintrich, \& M. Zeidner (Eds.), Handbook of self-regulation (pp. 111-169). Academic Press. https://doi.org/10.1016/B978-012109890-2/50034-2 
Kuhl, J., \& Fuhrmann, A. (2004). Selbststeuerungs-Inventar Kurzversion: SSI-K3 [the self-regulation inventory short version]. University of Osnabrück. Unpublished manuscript.

Lambert, M. J., \& Barley, D. E. (2001). Research summary on the therapeutic relationship and psychotherapy outcome. Psychotherapy: Theory, Research, Practice, Training, 38, 357-361. https://doi. org/10.1037/0033-3204.38.4.357

Lamm, C., Batson, C. D., \& Decety, J. (2007). The neural substrate of human empathy: Effects of perspective-taking and cognitive appraisal. Journal of Cognitive Neuroscience, 19, 42-58. https:// doi.org/10.1162/jocn.2007.19.1.42

Latham, G. P., \& Locke, E. A. (1991). Self-regulation through goal setting. Organizational Behavior and Human Decision Processes, 50(2), 212-247. https://doi.org/10.1016/0749-5978(91)90021-K

Lawrence, E. J., Shaw, P., Giampietro, V. P., Surguladze, S., Brammer, M. J., \& David, A. S. (2006). The role of 'shared representations' in social perception and empathy: An fMRI study. NeuroImage, 29(4), 1173-1184. https://doi.org/10.1016/j.neuroimage.2005. 09.001

Leiberg, S., \& Anders, S. (2006). The multiple facets of empathy: A survey of theory and evidence. Progress in Brain Research, 156, 419-440. https://doi.org/10.1016/s0079-6123(06)56023-6

Li, W.-D., Fay, D., Frese, M., Harms, P. D., \& Gao, X. Y. (2014). Reciprocal relationship between proactive personality and work characteristics: A latent change score approach. Journal of Applied Psychology, 99(5), 948-965. https://doi.org/10.1037/ a0036169

Locke, E. A., \& Latham, G. P. (Eds.). (2013). New changes in goal setting and task performance. Routledge. https://doi.org/10.4324/ 9780203082744

Lyubomirsky, S., King, L., \& Diener, E. (2005). The benefits of frequent positive affect: Does happiness lead to success? Psychological Bulletin, 131(6), 803-855. https://doi.org/10.1037/00332909.131.6.803

Magill, M., Apodaca, T. R., Borsari, B., Gaume, J., Hoadley, A., Gordon, R. E. F., \& Moyers, T. (2018). A meta-analysis of motivational interviewing process: Technical, relational, and conditional process models of change. Journal of Consulting and Clinical Psychology, 86(2), 140-157. https://doi.org/10.1037/ccp0000250

Mäthner, E., Jansen, A., \& Bachmann, T. (2005). Wirksamkeit und Wirkfaktoren von coaching [effectiveness and effect factors in coaching]. In C. Rauen (Ed.), Handbuch coaching (pp. 55-75). Hogrefe.

Miller, W. R., \& Rollnick, S. (2013). Motivational interviewing: Helping people change (3rd ed.). Guilford Press.

Moudatsou, M., Stavropoulou, A., Philalithis, A., \& Koukouli, S. (2020). The role of empathy in health and social care professionals. Healthcare, 8(1), 1-9. https://doi.org/10.3390/healthcare 8010026

Muck, P. M., Hell, B., \& Gosling, S. D. (2007). Construct validation of a short five-factor model instrument a self-peer study on the German adaptation of the ten-item personality inventory (TIPI-G). European Journal of Psychological Assessment, 23(3), 166-175. https://doi.org/10.1027/1015-5759.23.3.166

Myers, M. W., Laurent, S. M., \& Hodges, S. D. (2014). Perspective taking instructions and self-other overlap: Different motives for helping. Motivation and Emotion, 38(2), 224-234. https://doi. org/10.1007/s11031-013-9377-y

Neukom, M., Schnell, K., \& Boothe, B. (2011). Die Arbeitsbeziehung im Coaching [The working alliance in coaching]. Organisationsberatung, Supervision, Coaching, 16(3), 317-332.

O'Broin, A., \& Palmer, S. (2006). The coach-client relationship and contributions made by the coach in improving coaching outcome. The Coaching Psychologist, 2(2), 16-20.

Packard, M. D., \& Burnham, T. A. (2021). Do we understand each other? Toward a simulated empathy theory for entrepreneurship.
Journal of Business Venturing, 36(1), 106076. https://doi.org/10. 1016/j.jbusvent.2020.106076

Paulus, C. (2009). Der Saarbrücker Persönlichkeitsfragebogen SPF (IRI) zur Messung von Empathie: Psychometrische evaluation der deutschen version des interpersonal reactivity index [the Saarbrückener personality questionnaire to measure empathy: Psychometric evaluation of a German version of the interpersonal reactivity index]. University of Saarland. Retrieved from http://psydok.sulb.uni-saarland.de/volltexte/2009/2363/

Preacher, K. J., \& Hayes, A. F. (2008). Asymptotic and resampling strategies for assessing and comparing indirect effects in multiple mediator models. Behavior Research Methods, 40(3), 879-891. https://doi.org/10.3758/BRM.40.3.879

Preston, S. D., \& Hofelich, A. J. (2011). The many faces of empathy: Parsing empathic phenomena through a proximate, dynamic-systems view of representing the other in the self. Emotion Review, 4(1), 24-33. https://doi.org/10.1177/1754073911421378

Quirin, M., \& Kuhl, J. (2018). The self-access form-Change and validation in the context of personality. Journal of Individual Differences, 39(1), 1-17. https://doi.org/10.1027/1614-0001/a000244

Rekalde, I., Landeta, J., \& Albizu, E. (2015). Determining factors in the effectiveness of executive coaching as a management change tool. Management Decision, 53(8), 1677-1697. https://doi.org/ 10.1108/MD-12-2014-0666

Rogers, C. R. (1975). Empathic: An unappreciated way of being. The Counseling Psychologist, 5(2), 2-10.

Rusbult, C. E., \& Van Lange, P. A. (2003). Interdependence, interaction, and relationships. Annual Review of Psychology, 54(3), 351-375. https://doi.org/10.1146/annurev.psych.54.101601. 145059

Ryan, R. M., \& Deci, E. L. (2000). The darker and brighter sides of human existence: Basic psychological needs as a unifying concept. Psychological Inquiry, 11(4), 319-338. https://doi.org/10. 1207/S15327965PLI1104_03

Schiemann, S. J., Mühlberger, C., \& Jonas, E. (2018). Striving for autonomy: The importance of the autonomy need and its support within coaching. International Journal of Evidence Based Coaching and Mentoring, 16(1), 98-110. https://doi.org/10. 24384/000543

Schmidt, F. \& Thamm, A. (2008). Wirkungen und Wirkfaktoren im coaching [effects and effect factors in coaching]. University of Osnabrück.

Sheldon, K. M., \& Elliot, A. J. (1999). Goal striving, need satisfaction, and longitudinal well-being: The self-concordance model. Journal of Personality and Social Psychology, 76(3), 482-497. https://doi.org/10.1037/0022-3514.76.3.482

Sonesh, S. C., Coultas, C. W., Marlow, S. L., Lacerenza, C. N., Reyes, D., \& Salas, E. (2015). Coaching in the wild: Identifying factors that lead to success. Consulting Psychology Journal, 67(3), 189-217. https://doi.org/10.1037/cpb0000042

Staemmler, F.-M. (2008). Empathie in der Psychotherapie [empathy in psychotherapy]. University of Kassel. Unpublished doctoral dissertation. Retrieved from https://kobra.bibliothek.unikassel. de/bitstream/urn:nbn:de:hebis:342009022526404/3/Dissertati onStaemmler.pdf

Stein, D., \& Grant, A. M. (2014). Disentangling the relationships among self-reflection, insight, and subjective well-being: The role of dysfunctional attitudes and core self-evaluations. The Journal of Psychology: Interdisciplinary and Applied, 148(5), 505-522. https://doi.org/10.1080/00223980.2013.810128

Stober, D. R. (2006). Coaching from the humanistic perspective. In D. R. Stober \& A. M. Grant (Eds.), Evidence based coaching handbook: Putting best practices to work for your clients (pp. 17-50). Wiley. 
Stotland, E. (1969). Exploratory investigations of empathy. In L. Berkowitz (Ed.), Advances in experimental social psychology (Vol. 4, pp. 271-314). Academic Press.

Sullivan, M. A. (2006). The effectiveness of executive coaching in the change of emotional intelligence [unpublished doctoral dissertation]. Spalding University.

Theeboom, T., Beersma, B., \& van Vianen, A. E. M. (2014). Does coaching work? A meta-analysis on the effects of coaching on individual level outcomes in an organizational context. The Journal of Positive Psychology, 1(9), 1-18. https://doi.org/10.1080/ 17439760.2013.837499

Van Boven, L., \& Loewenstein, G. (2003). Social projection of transient drive states. Personality and Social Psychology Bulletin, 29(9), 1159-1168. https://doi.org/10.1177/0146167203254597

Van Boven, L., \& Loewenstein, G. (2005). Empathy gaps in emotional perspective taking. In B. F. Malle \& S. D. Hodges (Eds.), Other minds: How humans bridge the divide between self and others (pp. 284-297). Guilford Press.

Van Boven, L., Loewenstein, G., Dunning, D., \& Nordgren, L. F. (2013). Changing places: A dual judgment model of empathy gaps in emotional perspective taking. In J. M. Olson \& M. P. Zanna (Eds.), Advances in experimental social psychology (Vol. 48, pp. 117-171). Academic Press.

Vorauer, J. D. (2006). An information search model of evaluative concerns in intergroup interaction. Psychological Review, 113(4), 862-886. https://doi.org/10.1037/0033-295x.113.4.862

Vorauer, J. D., \& Sasaki, S. J. (2014). Distinct effects of imagine-other versus imagine-self perspective-taking on prejudice reduction. Social Cognition, 32(2), 130-147. https://doi.org/10.1521/soco. 2014.32.2.130

Watson, J. C. (2001). Revisioning empathy: Theory, research and practice. In D. Cain \& J. Seeman (Eds.), Handbook of research and practice in humanistic psychotherapy (pp. 445-472). APA Books.

Watson, J. C. (2007). Facilitating empathy. European Psychotherapy, $7(1), 59-65$

Watson, J. C., Steckley, P. L., \& McMullen, E. J. (2013). The role of empathy in promoting change. Journal of Psychotherapy Research, 24(3), 286-298. https://doi.org/10.1080/10503307. 2013.802823
Weber, J. (2013). Turning duty into joy! Optimierung der Selbstregulation durch motto-Ziele [turning duty into joy! Optimization of self-regulation due to motto goals]. Unpublished doctoral dissertation Retrieved from https://zrm.ch/daten/Dissertation\%20Jul ia\%20Weber\%20TurningDutyintoJoy_2013.pdf

Weisz, E., \& Cikara, M. (2021). Strategic regulation of empathy. Trends in Cognitive Sciences, 25(3), 213-227. https://doi.org/10.1016/j. tics.2020.12.002

Wieck, C., Kunzmann, U., \& Scheibe, S. (2021). Empathy at work: The role of age and emotional job demands. Psychology and Aging, 36(1), 36-48. https://doi.org/10.1037/pag0000469

Will, T., Gessnitzer, S., \& Kauffeld, S. (2016). You think you are an empathic coach? Maybe you should think again. The difference between perceptions of empathy vs. empathic behavior after a person-centered coaching training. Coaching: An International Journal of Theory, Research and Practice, 9(1), 53-68. https:// doi.org/10.1080/17521882.2016.1143023

Willms, J.-F. (2004). Coaching zur Umsetzung persönlicher Ziele. Entwicklung, Durchführung und evaluation [coaching to implement personal goals. Development, implementation and evaluation]. Unpublished doctoral dissertation. University of Osnabrück.

Wondra, J. D., \& Ellsworth, P. C. (2015). An appraisal theory of empathy and other vicarious emotional experiences. Psychological Review, 122(3), 411-428. https://doi.org/10.1037/a0039252

Wynn, R., \& Wynn, M. (2006). Empathy as an interactionally achieved phenomenon in psychotherapy - characteristics of some conversational resources. Journal of Pragmatics, 38, 1385-1397. https://doi.org/10.1016/j.pragma.2005.09.008

Yik, M., Russell, J. A., \& Steiger, J. H. (2011). A 12-point circumplex structure of core affect. Emotion, 11(4), 705-731. https://doi. org/10.1037/a0023980

Zaki, J. (2017). Moving beyond stereotypes of empathy. Trends in Cognitive Sciences, 21(2), 59-60. https://doi.org/10.1016/j.tics. 2016.12.004

Publisher's note Springer Nature remains neutral with regard to jurisdictional claims in published maps and institutional affiliations. 